\title{
Exchange on the Eleventh Amendment
}

\section{Calvin R. Massey†}

The principal battleground upon which Professor Fletcher and I joust is that of history. Professor Fletcher makes four criticisms of my reading of history, but each fails to demonstrate the superiority of his historical interpretation.

The "Plain Meaning" of the Text. Professor Fletcher's best argument is that the phrase employed in the Eleventh Amendment-." $t]$ he Judicial power ... shall not be construed to extend"-was intended to accomplish no more than repeal of the two party-based heads of federal jurisdiction addressed in the amendment. Professor Fletcher argues that Senator Breckenridge used the same language in an amendment proposed in 1875, which, as explained by Representative Elliot, would have repealed all diversity jurisdiction. ${ }^{1}$

But if the text was as clear as Professor Fletcher supposes, why did Chief Justice Marshall go to such lengths when deciding Eleventh Amendment cases to avoid stating that federal question jurisdiction of suits against states was unimpaired by the amendment? ${ }^{2}$ Professor Fletcher will answer that the Court never needed to say so because the trial courts did not have general federal question jurisdiction, but Justice Marshall readily delivered dicta concerning the scope of the Eleventh Amendment. In Osborn v Bank of the United States, ${ }^{3}$ for example, Marshall observed that the Eleventh Amendment "has its full effect, if the constitution be construed as it would have been construed, had the jurisdiction of the Court never been extended to suits brought against a State, by the citizens of another State, or by aliens." While Professor Fletcher relies heavily on this quote, ${ }^{5}$ it does not clinch his argument because Henry Clay made Professor Fletcher's point in his

$\dagger$ Associate Professor of Law, University of California, Hastings College of the Law.

- William A. Fletcher, The Diversity Explanation of the Eleventh Amendment: A Reply to Critics, $56 \mathrm{U}$ Chi L Rev at 1261, 1276-78 (1989).

${ }^{2}$ See generally, Calvin R. Massey, State Sovereignty and the Tenth and Eleventh Amendments, 56 U Chi L Rev 61, 120-35 (1989).

322 US (9 Wheat) 738 (1819).

- Id at 857-58.

s See Fletcher, $56 \mathrm{U}$ Chi L Rev at 1264 (cited in note 1). 
argument to the Court and Marshall rejected it by constructing the party-of-record rule in Osborn. ${ }^{6}$

Professor Fletcher's argument also fails to account adequately for Cohens $v$ Virginia, ${ }^{7}$ where Justice Marshall seemed to say that the Eleventh Amendment does not disturb federal question jurisdiction. ${ }^{8}$ If Marshall really believed that, however, the Court could have avoided the Eleventh Amendment by noting that the Cohens were asserting a federal question defense to the Virginia prosecution. Instead, Marshall chose to rely on the Cohens' Virginia citizenship.

The Rejected Gallatin Amendment. In Professor Fletcher's view, Congress rejected Senator Gallatin's proposed language excepting treaty claims from the Eleventh Amendment's operation in order to preclude the assertion of treaty claims under the statecitizen diversity heads of jurisdiction; treaty claims could still be asserted under other heads of jurisdiction. ${ }^{\circ}$ The problem is that the evidence is persuasive-and Fletcher concedes - that the Eleventh Amendment was animated by a desire to protect state treasuries. If the amendment preserved federal question jurisdiction for treaty claims, it would not have completely protected state treasuries from these claims.

Professor Fletcher assumes either (1) that the anti-federalist proponents of the Eleventh Amendment were willing to tolerate the possibility of claims against states under federal question jurisdiction, or (2) that the anti-federalists were unable to muster a majority to eliminate federal question jurisdiction of claims against states by outsiders. Professor Fletcher disables himself from relying on the first assumption by conceding that the ambition of the Eleventh Amendment was to protect state treasuries. He speculates that uncertainty about congressional ability to abrogate state sovereign immunity in federal question cases was enough to satisfy the anti-federalists. ${ }^{10}$ Given the passionate growl of opposition to Chisholm $v$ Georgia, ${ }^{11}$ I do not think this very likely.

The second possibility is more promising for, after all, the anti-federalists lacked the strength to obtain passage of Representative Sedgwick's version of the Eleventh Amendment, which

- See Massey, 56 U Chi L Rev at 130-33 (cited in note 2).

19 US (6 Wheat) 264 (1821).

8 Id at 392 (federal judicial power "extends to all cases arising under the constitution or a law of the United States, whoever may be the parties").

- Fletcher, 56 U Chi L Rev at 1285-87 (cited in note 1).

10 Id at 1287.

$" 2$ US 363, 2 Dall 419 (1793). 
would have assured complete immunity to the states. Given the rejection of both the Sedgwick and Gallatin proposals, we can be reasonably certain that the final version of the Eleventh Amendment embodied a compromise. Almost everyone agrees that the text is badly drafted, a hallmark of political compromise. My explanation accounts much better for the awkward compromise than does Professor Fletcher's, which portrays the anti-federalists as complacent and short-sighted, inexplicably agreeing to a compromise inadequate to its purpose. ${ }^{12}$

If the Eleventh Amendment preserved the jurisdictional bite of the federal courts upon the states whenever a federal question was present, Professor Fletcher is compelled to explain why Chief Justice Marshall failed to cement that federalist victory when he was given the chance to do so, obliquely in Cohens and directly in Osborn. Professor Fletcher's failure to do so unravels his explanation.

The Assignment Problem. Professor Fletcher observes that my reading treats the anti-federalists as "inept" by virtue of their failure to prohibit assignment of claims to in-staters. ${ }^{13}$ Rather, I contend that the anti-federalists accepted a certain measure of risk that such assignments could occur but thought, correctly in my view, that such collusive, jurisdiction-manufacturing assignments would be judicially precluded. Section 11 of the 1789 Judiciary Act deprived the circuit courts of diversity jurisdiction over suits brought by an assignee "unless a suit might have been prosecuted in such court . . . if no assignment had been made."14 This provision could have been interpreted to defeat collusive assignments made in order to avoid the party-based bar of the Eleventh Amendment. ${ }^{15}$

The Supreme Court construed other provisions of $\S 11$ to comport with the constitutional limits of federal judicial power. In

\footnotetext{
12 Professor Fletcher must make the heroic assumption that the antifederalists complacently accepted the possibility of congressional resuscitation of the disfavored claims via a general grant of federal question jurisdiction. Since Congress did just that only three years later, in the short-lived Judiciary Act of 1801, Professor Fletcher's implicit assumption is most improbable. See Act of Feb 13, 1801, ch 4, 2 Stat 89, repealed by Act of March 8, 1802, ch 8, 2 Stat 132; and see Massey, $56 \mathrm{U}$ Chi L Rev at 114-15 \& n 281 (cited in note 2).

${ }^{13}$ Fletcher, $56 \mathrm{U}$ Chi L Rev at 1287 (cited in note 1).

14 Judiciary Act of 1789 , ch $20, \S 11,1$ Stat 73,79 .

15 It is instructive, though of course not dispositive, that $\S 11$ has evolved to divest the district courts of all jurisdiction when a "party, by assignment or otherwise, has been improperly or collusively . . . joined to invoke [] jurisdiction." 28 USC § 1359 (1982). Compare New Hampshire $v$ Louisiana, 108 US 76 (1883), discussed in Massey, 56 U Chi L Rev at 137-38 (cited in note 2).
} 
Mossman v Higginson ${ }^{16}$ and Hodgson $v$ Bowerbank, ${ }^{17}$ for example, the Court narrowly construed the affirmative jurisdictional grant of $\S 11$ (over cases involving aliens). If the anti-federalists sought in the Eleventh Amendment to create a party-based bar to federal jurisdiction, the logic of Mossman and Hodgson suggests that the statutory bar would be construed as coterminous with the constitutional limits of federal jurisdiction, thus prohibiting jurisdiction derived from assignments that eliminated the fatal party alignment.

The Use of a Constitutional Amendment Instead of Legislation to Overturn Chisholm. Professor Fletcher asserts that this choice tells us very little about the intentions of the adopters and was most likely due to uncertainty over whether the Court's jurisdiction was self-executing. ${ }^{18}$ But resolution of the latter point has a great deal to do with the former.

Contrary to Professor Fletcher's suggestion, the actors of the time were likely not in agreement that the Court's original jurisdiction was self-executing. ${ }^{19}$ Professor Fletcher must explain Congress' inclusion, in $\S 13$ of the 1789 Judiciary Act, ${ }^{20}$ of a jurisdictional grant encompassing a portion of the Court's original jurisdiction. He must also account for the virtual silence of Justice Iredell's four colleagues in Chisholm in the face of the public disagreement between Attorney General Randolph and Justice Iredell over this issue. ${ }^{21}$

I submit that Professor Fletcher has not carried the burden of persuasion on this point, and that the use of a constitutional amendment was likely due to a desire "to guarantee perma-

18 4 US 11, 12-13, 4 Dall 12 (1800).

179 US (5 Cranch) 303, 304 (1809).

18 Fletcher, $56 \mathrm{U}$ Chi L Rev at 1288-89 (cited in note 1).

18 Massey, 56 U Chi L Rev at 116-17 (cited in note 2). Professor Fletcher has somewhat altered his view; he now contends "that four of the five justices in Chisholm might reasonably have been thought by the adopters of the Eleventh Amendment to have held [the opinion that the Court's jurisdiction was self-executing]." Fletcher, $56 \mathrm{U}$ Chi L Rev at $1289 \mathrm{n}$ 141 (cited in note 1).

20 Judiciary Act of 1789 , ch $20, \S 13,1$ Stat 80 .

212 US at 373. Professor Fletcher relies upon Robert N. Clinton, A Mandatory View of Federal Court Jurisdiction: Early Implementation of and Departures from the Constitutional Plan, 86 Colum L Rev 1515, 1563-68 (1986), for the proposition that Justice Iredell's four brethren agreed with Randolph that the Court's original jurisdiction was self-executing. Fletcher, $56 \mathrm{U}$ Chi L Rev at 1289 n 140 (cited in note 1). But even Professor Clinton, a staunch defender of the idea that Article III created federal jurisdiction "that was not subject to diminishment or curtailment by the other branches" of government, 86 Colum L Rev at 1516, admits that Justices Cushing, Blair and Jay did not "directly address[] the debate." Id at 1567. Only Justice Wilson was clearly in Randolph's camp. 
nency."22 Permanency would not result from either a statutory or constitutional repeal of party-based jurisdiction conferred by $\S 13$ of the Judiciary Act. The reason is simple: the joker of federal question jurisdiction would remain. Only the erection of a new, and constitutional, barrier to the exercise of federal jurisdiction over claims held by the disfavored classes would suffice.

Contemporary Theory and Policy. Professor Fletcher and I agree that the Eleventh Amendment does not answer the question of whether there are other constitutional limitations that might vest the states with sovereign immunity from suit in the federal courts. We agree that the Tenth Amendment, or principles borrowing from its spirit, are the source of any such limitations. Reconstructing the Eleventh Amendment is a small step toward recognizing that the Tenth Amendment has independent, normative teeth that impinge upon the exercise of federal judicial power directly against the states.

\section{William P. Marshall ${ }_{\dagger}$}

Professor Fletcher's claim that he and I are in substantial agreement might initially seem odd. ${ }^{1}$ Fletcher's diversity theory implies that states could be subject to federal question jurisdiction in federal court. My conclusion-that states may enjoy some constitutional protection from suit in federal court-is near the opposite end of the spectrum.

Yet we are in fact in substantial agreement. As Professor Fletcher recognizes, my position is narrow. I do not argue that states are immune from all federal question suits. Rather, I take the position that the diversity theorists have failed to show that states are not entitled to immunity from suits seeking monetary relief. Professor Fletcher, if I read him correctly, does not categorically deny that states might enjoy this limited immunity. $\mathrm{He}$ contends that any such immunity cannot properly be ascribed to the Eleventh Amendment. ${ }^{2}$

${ }^{22}$ See Clinton, 86 Colum L Rev at 1558.

$\dagger$ Professor of Law, Case Western Reserve University Law School.

${ }_{1}$ William A. Fletcher, The Diversity Explanation of the Eleventh Amendment: A Reply to Critics, 56 U Chi L Rev 1261, 1290 (1989).

2 Id at 1298-99. 
Nonetheless, the Eleventh Amendment and the light it sheds on the availability of federal jurisdiction over suits against states for monetary relief is the basis of our disagreement. Before proceeding to this issue, however, some background is in order.

One of the central issues in the federalist/anti-federalist debate during the constitutional ratification process concerned the degree to which the states would surrender their sovereignty in joining the Union. This debate was essentially won by the federalists. As a result, the "plan of the convention" required the states to surrender some of their independent sovereignty. I agree with Fletcher that the "plan of the convention" also supports some measure of federal jurisdiction over the states; an effective compact presupposes at least some degree of enforceability.

However, the availability of federal jurisdiction over suits against the states for monetary relief-the key issue underlying my disagreement with Professor Fletcher-was not seen as implicating broad theoretical concerns of federal/state relations. As I read the history, the state immunity issue attracted only limited attention in the ratification process and any debate that did occur was not fought along federalist/anti-federalist lines. Both federalists as well as anti-federalists argued against federal court jurisdiction over suits against states for monetary relief.

This is not to say that the sentiment for state immunity was unanimous. James Wilson and Edmund Randolph argued in favor of state suability. ${ }^{3}$ Additionally, the only pre-amendment Supreme Court decision to address the immunity issue, Chisholm $v$ Georgia ${ }^{4}$ (a case in which both Wilson and Randolph actively advanced their position) held that states could be subject to federal court suit for monetary relief.

Significantly, however, this pre-amendment support for state suability was repudiated. The Eleventh Amendment was passed expressly to overturn Chisholm. Moreover, it was passed with the overwhelming support of both federalists and anti-federalists, again suggesting that state immunity was not considered to be a threat to the federalists' plan of the convention. ${ }^{5}$ The reason for

\footnotetext{
3 The Debates in the Several State Conventions on the Adoptions of the Federal Constitution at 1491 (Elliot ed. 1881) (Wilson); and id, vol 3 p 573 (Randolph). Wilson's comments on state suability for damages are more ambiguous than are Randolph's.

+ 2 US 363, 2 Dall 419 (1793).

Diversity theorists would argue that the federalists did not oppose the Eleventh Amendment because the elimination of diversity jurisdiction against the states did not com-
} 
this is relatively apparent. State immunity was not particularly divisive because the federalists and anti-federalists shared a common concern for protecting state treasuries from federal judicial invasion. ${ }^{\mathrm{B}}$

Professor Fletcher agrees that the drafters of the Eleventh Amendment were concerned with protecting state treasuries. $\mathrm{He}$ also agrees that the framers were aware that federal question suits were potentially available to plaintiffs seeking relief from state treasuries and that existing common-law claims against the states could be characterized as claims based on federal law. ${ }^{7}$ Where we disagree is on how these conclusions relate to the state immunity issue.

I conclude that the framers of the Eleventh Amendment most probably expected its grant of state immunity to extend to federal, as well as common-law, claims for monetary relief. Applying state immunity only to non-federal claims would not protect state treasuries, especially since possible federal claims existed. Accordingly, the construction most consistent with the goal of protecting state treasuries is that state immunity should apply to all claims for monetary relief against the states. Significantly, this construction also accords with the drafters' apparent view that governmental immunity from monetary relief was not inconsistent with the constitutional plan. There was, after all, no significant dissent to the proposition that the federal government enjoyed immunity from damage actions.

Professor Fletcher's response, as I understand it, is three-fold. First, he asserts that the basis of any case for state immunity from federal question suits must exist outside of the Eleventh Amendment. Accordingly, Fletcher's arguments supporting the diversity theory are confined to the text and history of the amendment. Professor Fletcher's thesis does not purport to resolve whether the pre-Eleventh Amendment Constitution allowed the states to be sued in federal court for monetary relief; he notes that there is evidence on both sides.

I question, however, whether the meaning of the Eleventh Amendment can be so readily divorced from the pre-amendment

promise a significant federal interest. This assumes that the drafters distinguished between federal and non-federal claims against the states. As will be discussed subsequently, this is a difficult assumption to establish.

' Some objected to Chisholm on the ground that subjecting states to suit was an affront to their sovereignty. This rationale and the fiscal protection rationale are probably related. The states felt that their sovereignty was challenged by the threat to their fiscal resources.

7 Fletcher, 56 U Chi L Rev at 1292 (cited in note 1). 
understanding of the constitutional basis for state immunity. The meaning of the Eleventh Amendment and the state immunity question have been, in history and precedent, inextricably bound. Since Hans $v$ Louisiana, "Eleventh Amendment immunity" has come to refer to both the amendment and any other constitutional basis for state immunity from suit in federal court. According to the Hans Court, the Eleventh Amendment did not need to explicitly exclude federal question suits from federal jurisdiction because the states were never intended to be amenable to federal court jurisdiction in the first place. ${ }^{9}$

Awkward as it may be, the Hans approach makes sense. The reaction of the Eleventh Amendment's drafters to Chisholm depended on their understanding of the pre-amendment constitutional basis for state immunity. They could have drafted the amendment to more clearly provide for complete state immunity from damage suits. ${ }^{10}$ However, if they believed that this protection already existed in the Constitution and that the Chisholm Court simply got it wrong, they only needed to draft a provision that responded to the Court's error. ${ }^{11}$

More importantly, the Hans understanding takes into account the amendment's conceded purpose of protecting state treasuries. Unless there were reasons why the drafters would have allowed federal claims against the states, yet disallowed non-federal claims, the Hans formulation is the only one that makes sense.

Professor Fletcher's final two arguments are attempts to explain why the drafters might have distinguished between federal and non-federal claims. He first contends that the drafters may not have addressed federal question suits because the lower courts did not then have general federal question jurisdiction. ${ }^{12} \mathrm{He}$ acknowledges that the Supreme Court could review state decisions involving federal questions, but asserts that this review did not significantly threaten state treasuries because the appeal route was long, uncertain, and untested. ${ }^{13}$ This may be so, but I am reluctant to accept an interpretion of the Constitution that attributes such

134 US 1 (1890).

- Id at 14-15.

10 I accept Professor Fletcher's point that any deficiencies in the amendment's drafting cannot be ascribed to haste. See Fletcher, $56 \mathrm{U}$ Chi L Rev at 1290-91 (cited in note 1).

11 This explanation is consistent with Professor Fletcher's contention that the Eleventh Amendment only addresses diversity suits because the framers only needed to clarify diversity jurisdiction after the Chisholm error.

${ }^{12}$ Fletcher, 56 U Chi L Rev at 1286 (cited in note 1).

13 Id at 1293. 
short-sightedness to the framers. The threat posed by Supreme Court review might not have been immediate, but it was real. Additionally, the creation of general federal question jurisdiction was not unforeseeable. Congress, in fact, approved such jurisdiction in 1801 (and repealed it in 1802). Indeed, the history of the 1801 adoption of general federal question jurisdiction is also significant because neither the adoption nor the 1802 repeal provoked discussion of the state immunity issue, indicating that Congress may have thought the Eleventh Amendment had resolved the issue. ${ }^{14}$

Professor Fletcher's final argument is that the drafters may have treated federal and non-federal claims differently because they viewed them as different in kind. Non-federal claims against the states (including those based on general common law as in Chisholm) were a matter of the state's own law and ultimately subject to state definition. Federal claims involved the law of another sovereign. Fletcher suggests that the questions raised by subjecting a state to its own law (as in Chisholm) and those raised by subjecting a state to the law of a superior sovereign are so different that the drafters would not have thought they involved the same answers. ${ }^{15} \mathrm{He}$ contends that since Chisholm involved only non-federal claims, it was only that threat that the framers of the Eleventh Amendment would have likely addressed.

I disagree. First, it is inaccurate to assume that the reaction to Chisholm can be explained as objection solely to federal court use (misuse) of a state's own law. The majority opinions in Chisholm, particularly those of Jay and Randolph, suggest that the Court was not simply interpreting common law. The Justices' assertion that sovereign immunity was incompatible with the new constitutional order does not read like a simple common-law rule from which a state could opt out. Certainly, I doubt that Georgia thought it could revive its immunity by passing a statute or issuing its own common-law decision declaring itself immune from common-law claims. Indeed, if states could have so easily departed from a "common-law" decision like Chisholm, as Fletcher suggests, they could have done so unilaterally, without passing a constitutional amendment. Yet there is no evidence that any state felt it could

\footnotetext{
14 For the amendments, see note 12 of Professor Massey's rebuttal. It is also somewhat backward to rely on the fact that the first Congress did not provide for general federal question jurisdiction to support the argument that only diversity claims should be barred from federal court. The exclusion of federal question jurisdiction militates against the conclusion that it was deemed necessary to effectuate the plan of the convention.

${ }^{15}$ Fletcher, $56 \mathrm{U}$ Chi L Rev at 1295-97 (cited in note 1).
} 
circumvent Chisholm in this manner. In short, something more was going on in Chisholm than mere interpretation of the state's own law.

It is also questionable to characterize Chisholm only as federal court application of a state's law against itself. In fact, two state laws were potentially implicated-that of the defendant-state (the debtor) and that of the plaintiff-citizen (the creditor). Chisholm, then, did present a case involving conflicts among multiple sovereigns. It might therefore fall as easily within Fletcher's second category, the use of one sovereign's (albeit not a superior sovereign's) law against another, rather than within his first, the use of a sovereign's law against itself. ${ }^{16}$

Finally, to repeat, Fletcher's distinction between federal and non-federal claims does not capture the objection to Chisholm. Both federal and non-federal claims could pose serious threats to state coffers. The concern with protecting state treasuries does not depend on the judicial categories of the suits.

Having made my argument in its strongest terms, I wish to retreat somewhat. I do not pretend to present the "true" historical account. Fletcher and I agree that the relevant history does not lead to a definitive resolution. But I have a trump card-stare decisis. Hans is no panacea and raises difficult issues. ${ }^{17}$ But anyone seeking to overturn a hundred-year-old precedent on historical grounds should have to come to more than a draw on disproving the precedent's historical assertions. The diversity theorists have not met this burden.

\section{Lawrence C. Marshall $\rceil_{\dagger}$}

Professor William Marshall concludes his response to Professor Fletcher by declaring that he, unlike Fletcher, has a trump card: stare decisis. Unless the evidence of the framers' intent is

\footnotetext{
${ }^{16}$ Admittedly, the issue of another state's law being applied against a state would vanish if diversity jurisdiction were repealed. However, the possible application of another state's law does weaken Fletcher's argument that the framers were concerned only with state immunity from its own law.

${ }^{17}$ The distinction between claims for retrospective and prospective relief, 134 US at 2021 , is particularly troublesome.
}

$\dagger$ Assistant Professor, Northwestern University School of Law. 
unambiguous, Marshall argues, it is appropriate to stick with the hundred year old precedent of Hans $v$ Louisiana. ${ }^{1}$ I, too, claim to have a trump card, a card so strong that it trumps even a hundred years of constitutional precedent. As I have argued before, ${ }^{2}$ the clear and unambiguous dictates of the Eleventh Amendment's text should be respected unless it can be proven that they do not reflect the intent of the amendment's framers and ratifiers.

As far as I can tell, Professor Fletcher does not challenge my general approach to the issue. Instead, he asserts that the language of the Eleventh Amendment is far from unambiguous, and may even be moderately clear in support of the diversity theory. ${ }^{3}$ If Professor Fletcher is correct, then my trump card is counterfeit and my historical explanation for the amendment is entitled to no preference over competing theories. Happily, at least for me, I remain convinced that he is wrong, and that the plain meaning of the amendment is clear and unequivocal-it forbids jurisdiction whenever an out-of-stater or foreigner sues a state.

To briefly review my argument, I contend that the Eleventh Amendment is exceptionally clear on the question of who may bring suit against a state in federal court: "The Judicial power of the United States shall not be construed to extend to any suit in law or equity, commenced or prosecuted against one of the United States by Citizens of another State, or by Citizens or Subjects of any Foreign State." The plain meaning of these words refutes the diversity theorists' claim that any citizen, including a citizen of another state or a foreign citizen, may bring some types of suits against a state in federal court, such as suits arising under federal question jurisdiction. $^{4}$

Professor Fletcher's only response to this assertion is that I ignore important evidence regarding near-contemporary usage of the amendment's language. In 1805, he explains, Senator Breckenridge proposed an amendment apparently designed to eliminate some types of party-based jurisdiction. Breckenridge's proposed amendment was as follows:

The judicial power of the United States shall not be construed to extend to controversies between a State and citizens of an-

\footnotetext{
134 US 1 (1890).

${ }^{2}$ Lawrence C. Marshall, Fighting the Words of the Eleventh Amendment, 102 Harv L Rev 1342 (1989).

${ }^{3}$ William A. Fletcher, The Diversity Explanation of the Eleventh Amendment: A Reply to Critics, 56 U Chi L Rev 1261, 1276-78 (1989).

+ See L. Marshall, 102 Harv L Rev at 1346-49 (cited in note 2).
} 
other State, between citizens of different states, between citizens of the same State, claiming lands under the Grants of different States, and between a State, or the citizens thereof and foreign States, citizens, or subjects. ${ }^{5}$

Common sense and evidence of contemporary understanding of the proposed amendment confirm that Breckenridge was not trying to eliminate all jurisdiction over suits between states and citizens of other states, or between citizens and citizens. ${ }^{6}$ Yet, Fletcher argues, given a literal reading based on the dominant interpretation of the Eleventh Amendment, Breckenridge's proposed amendment would compel just that absurd result, gutting federal jurisdiction. Hence, Professor Fletcher concludes, usage at the turn of the nineteenth century must have been different from our modern usage. Professor Akhil Amar has made a similar argument, also relying on this line of proposed amendments. ${ }^{7}$

One problem with Fletcher and Amar's argument is that it ignores the specific language of Breckenridge's proposal. Breckenridge did not use the Eleventh Amendment's broad language, barring "any suit in law or equity" brought against a state by an enumerated party. Instead, he focused on "controversies" among the enumerated parties. This distinction is crucial. Article III lists nine heads of federal jurisdiction. The first three are defined by subject matter and are labelled as "cases." The next six are partybased, and are labeled as "controversies." "Amar himself has pointed out that Article III distinguishes "between, on the one hand, federal question, admiralty, and ambassador cases, which are all defined by subject matter, and, on the other, diversity-type controversies, which are all defined by party status." 10 If, as

B 14 Annals of Congress 53 (Feb 8, 1805). During 1806 and 1807, Senators Maclay and Clay introduced almost identical proposals. See 15 Annals of Congress 68 (Jan 22, 1806) (Senator Maclay); 16 Annals of Congress 76 (Feb 20, 1807) (Senator Clay).

- See Fletcher, 56 U Chi L Rev at 1277 (cited in note 3).

? See Akhil Reed Amar, Of Sovereignty and Federalism, 96 Yale L J 1425, 1482-83 n 233 (1987).

8 "The judicial Power shall extend to all Cases, in Law and Equity, arising under this Constitution, the Laws of the United States, and Treaties made, or which shall be made, under their Authority;- to all Cases affecting Ambassadors, other public Ministers and Consuls;-to all Cases of admiralty and maritime Jurisdiction. ..." US Const, Art III, § 2, cl 1 (emphasis added).

" "-to Controversies to which the United States shall be a Party;-to Controversies between two or more States;-between a State and Citizens of another State;-between Citizens of different States;--between Citizens of the same State claiming Lands under Grants of different States, and between a State, or the Citizens thereof, and foreign States, Citizens or Subjects." US Const, Art III, $§ 2$, cl 1 (emphasis added).

10 Akhil Reed Amar, Law Story, 102 Harv L Rev 688, 716 (1989) (emphasis in original). 
Fletcher, Amar, and I agree, Breckenridge wished only to remove jurisdiction over certain of the party-based categories, he accomplished that by restricting his amendment to "controversies." By not mentioning "cases" or using the Eleventh Amendment's broad "any suit" formulation he avoided drafting an amendment that would bar all suits, including federal question, admiralty, and ambassador cases, involving the listed parties. Although Breckenridge modeled his proposal on the Eleventh Amendment, he deliberately departed from its broad formulation.11

This analysis rebuts Professor Fletcher's claim about thencontemporary usage and, to an extent, supports my literal reading of the Eleventh Amendment. But even if Breckenridge had been sloppy and actually copied the Eleventh Amendment's broader "any suit" language, I would not read too much into his defeated proposal. For all we know, the proposed amendment failed precisely because it was phrased too broadly. In any event, Breckenridge might have casually incorporated the existing words and structure of the Eleventh Amendment without realizing that he was creating a monster. It is far less likely that the framers of the Eleventh Amendment, working from scratch, would have chosen the words they did if they had meant to leave open some avenues of jurisdiction in the enumerated cases. Of course, given Breckenridge's precision in limiting his proposal to "controversies," it is unnecessary to pursue this hypothetical point.

Even if he were persuaded that the plain meaning of the text supports my construction of the amendment, Professor Fletcher would still, apparently, reject my view as incoherent. He contends that my theory falls apart because it leaves open the possibility that ineligible plaintiffs (out-of-state and foreign citizens) might assign or sell their claims to eligible plaintiffs (in-state citizens) who would, in turn, sue the state. Fletcher argues that leaving open this route of evasion would not "have been rational if the states were concerned about the impact on their treasuries (as everyone . . . concedes they were)."12 But Fletcher refuses to recognize that if my reading is rendered incoherent by the possibility of assign-

\footnotetext{
11 I am not suggesting an airtight distinction between cases and controversies. Nor am I claiming that there is only one way of understanding the terms; Professor Fletcher's evidence, in his response, of how cases and controversies were understood may well be correct. Indeed, Article III goes on to use the word "cases" in a seemingly general way when defining Supreme Court jurisdiction. But Breckenridge had something in mind when he opted not to follow the broad language of the Eleventh Amendment, and Article III's distinction between cases and controversies makes Breckenridge's words consistent with his likely goal.

${ }^{12}$ Fletcher, $56 \mathrm{U}$ Chi L Rev at 1281 (cited in note 3).
} 
ment, so is his! Even under the diversity theory, an ineligible plaintiff could have evaded the amendment by assigning his claim to an eligible plaintiff (such as a state or foreign government), which would then have sued the state. ${ }^{13}$

Of course, once federal question jurisdiction was created, such assignments were no longer always necessary under the diversity theory, because any citizen could sue a state if the case arose under federal law. But there was no general federal question jurisdiction at the time the Eleventh Amendment was adopted, and the use of assignments could have defeated the states' goal of preserving their fiscs.

Perhaps the answer to our mutual problem with assignments is that the framers of the Eleventh Amendment thought that the federal courts would not allow assignments to create federal jurisdiction. ${ }^{14}$ The key, however, is that we have fought to a draw on this point. And to paraphrase Professor William Marshall once again: anyone seeking to ignore the plain meaning of constitutional text "should have to establish more than a draw on the issue in controversy."

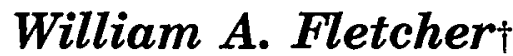

The diversity explanation holds that the Eleventh Amendment was intended to repeal that part of the state-citizen diversity clause of Article III that had conferred party-based jurisdiction over unconsented suits brought against the states by out-of-state citizens or aliens. ${ }^{1}$ The repeal of the clause did not prohibit jurisdiction over such suits under other clauses of Article III. If federal question jurisdiction over such suits existed before the passage of

\footnotetext{
1s This trick has been tried more than once. See L. Marshall, 102 Harv L Rev at 1366$67 \mathrm{n} 113$ (cited in note 2).

14 See L. Marshall, 102 Harv L Rev at 1366-67 n 113 (cited in note 2), in addition to Professor Massey's letter.

$\dagger$ Professor of Law, University of California, Berkeley, School of Law (Boalt Hall).

1 In addition to the longer explanation offered in the piece prompting this exchange, William A. Fletcher, The Diversity Explanation of the Eleventh Amendment: A Reply to Critics, 56 U Chi L Rev 1261, 1264-75 (1989), see the original exposition of my diversity explanation in William A. Fletcher, A Historical Interpretation of the Eleventh Amendment: A Narrow Construction of an Affirmative Grant of Jurisdiction Rather than a Prohibition Against Jurisdiction, 35 Stan L Rev 1033 (1983).
} 
the Eleventh Amendment, it continued to exist after its passage. In my view, it was an open question whether federal question jurisdiction permitted unconsented suits, either before or after the amendment.

\section{Reply to Professors Lawrence Marshall and Massey}

Professors Lawrence Marshall and Calvin Massey contend that the Eleventh Amendment bars suits brought by out-of-staters against unconsenting states regardless of whether another source of jurisdiction exists. Professor Marshall thinks that the amendment does not bar suits by in-staters;' Professor Massey thinks that the amendment may have been intended to bar suits by in-staters, but is not confident that this is so. ${ }^{3}$ Both think that unconsented suits were available under the federal question jurisdiction where not prohibited by the Eleventh Amendment.

\section{A. The "Plain Meaning of the Text"}

In their earlier pieces, Professors Marshall and Massey had argued that the "plain meaning of the text" prohibits all suits brought against states by out-of-state citizens, regardless of the source of jurisdiction. ${ }^{4}$ I responded that an amendment drafted by Senator Breckenridge of Kentucky and unsuccessfully proposed in 1805,1806 , and 1807 shows that the words of the Eleventh Amendment had a relatively familiar meaning at the end of the eighteenth century. ${ }^{5}$ Breckenridge's proposed amendment read, "The judicial power ... shall not be construed to extend to controversies between ... citizens of different states." The crux of the argument is the phrase, "the judicial power . . . shall not be construed to extend." Does it bar all suits where the parties are aligned in the specified ways? Or does it bar such suits only when the alignment of the parties is the basis for jurisdiction? It is clear that Breckenridge intended the second, for we know that he did not intend to

\footnotetext{
${ }^{2}$ Lawrence C. Marshall, Fighting the Words of the Eleventh Amendment, 102 Harv L Rev 1342, 1346 (1989).

${ }^{3}$ Calvin R. Massey, State Sovereignty and the Tenth and Eleventh Amendments, 56 U Chi L Rev 61, 119 (1989).

' L. Marshall, 102 Harv L Rev at 1343, 1346, 1349, and 1371 (cited in note 2); Massey, $56 \mathrm{U}$ Chi L Rev at 65 and 115 (cited in note 3).

${ }^{5}$ Fletcher, 56 U Chi L Rev at 1276-79 (cited in note 1).

- 14 Annals of Congress 53 (Feb 8, 1805). Breckenridge's proposed amendment would also have eliminated other party-based heads of jurisdiction. I use citizen-citizen diversity as my example, but I could make the argument using any of the heads of jurisdiction that Breckenridge proposed to eliminate.
} 
bar federal jurisdiction whenever the parties were so aligned. ${ }^{7}$ If Breckenridge's proposed amendment is a reliable gloss, then the Eleventh Amendment did not bar federal question suits when the parties were so aligned.

Professor Marshall did not mention Senator Breckenridge's proposed amendment in his earlier article. He now advances an ingenious argument that, if successful, would substantially rehabilitate his plain meaning argument. He points out that Senator Breckenridge's proposed amendment used the term "controversies" and contends that the term "cases" is used in Article III whenever the head of jurisdiction is defined by subject matter, while the term "controversies" is used whenever the head of jurisdiction is defined by party alignment. Thus, Professor Marshall concludes, Breckenridge's amendment would have only barred party alignment as a basis for jurisdiction because "controversies" meant only suits whose jurisdiction depended on party alignment.

Professor Marshall's argument depends on a distinction between "cases" and "controversies" that did not exist at the time Breckenridge proposed his amendment. St. George Tucker explained in 1803 that "cases" referred to "all cases, whether civil or criminal"; "controversies" referred only to disputes "of a civil nature." ${ }^{\prime}$ Ten years earlier in Chisholm v Georgia, Justice Iredell expressed a similar understanding of "controversies," and thirty years later in his Commentaries, Justice Story defined "cases" and "controversies" as Tucker had done, citing Tucker as his authority. ${ }^{10}$ If the contemporary meaning of "controversies" was "civil suits," Professor Marshall's theory does not work. If Breckenridge's proposal would have forbidden all civil suits, not merely party-based suits, it would have forbidden civil federal question suits as well as diversity suits. Professor Marshall and I agree that Breckenridge did not intend that result.

Professor Massey's plain meaning argument is different. If the amendment was intended merely to repeal state-citizen diversity, he asks, why did Chief Justice Marshall avoid deciding that federal question jurisdiction permitted suits against unconsenting states? The answer is simple. We know that Marshall thought the amend-

7 Fletcher, 56 U Chi L Rev at 1277-78 (cited in note 1).

${ }^{8}$ St. George Tucker, ed, I Blackstone's Commentaries 420-21 (Birch and Small, 1803) (emphasis in original).

Chisholm $v$ Georgia, 2 US 363, 372-73, 2 Dall 419, 431-32 (1793) (Iredell dissenting).

10 Joseph Story, 3 Commentaries on the Constitution of the United States 536 n 2 (Hilliard, Gray, 1833, reprinted Da Capo Press, 1970). 
ment required us to read Article III as if it had never contained the state-citizen clause. ${ }^{11}$ But this does not tell us whether federal question jurisdiction existed for unconsented private suits against the states. That was a related, but different, issue. Marshall did equivocate on the issue of federal question jurisdiction (for reasons I will discuss in a moment), but he did not equivocate on whether the amendment operated as a repeal of the state-citizen clause.

\section{B. Assignment}

A weakness of Professors Lawrence Marshall and Massey's reading is that out-of-staters, who were barred from suit by the amendment, could have assigned their federal claims to in-staters, who were not barred by the amendment. If they are right that the amendment permits federal question suits brought by in-staters, the adopters were almost inconceivably inept. Why pass an amendment protecting the states against federal claims when that protection could be easily circumvented?

Professor Marshall responds that if the assignment problem renders his explanation of the amendment "incoherent," it does the same to the diversity explanation. He explains that under the diversity explanation "an ineligible plaintiff could have evaded the amendment by assigning his claim to an eligible plaintiff (such as a state or foreign government), which would then sue the state." This response misses the point of the diversity explanation. Under the diversity explanation, there are no "ineligible plaintiffs." A federal question suit can be brought by any party, assuming that the jurisdiction is supportable on its own merits. Only under Professor Marshall's explanation are there "ineligible plaintiffs" who are barred by the amendment from bringing suit.

Professor Massey responds that suits after assignments would not have been permitted. ${ }^{12}$ In his words, "[T] he anti-federalists ... thought . . . such collusive, jurisdiction-manufacturing assignments would be judicially precluded." Professor Massey does not cite an anti-federalist who said or wrote this. Instead, he asserts that $\S 11$ of the Judiciary Act of 1789 would have been read to bar jurisdiction. This is a daring, even startling, assertion. Section 11 con-

11 Osborn v Bank of United States, 22 US (9 Wheat) 738, 857-58 (1824) (Marshall) (The Eleventh Amendment "has its full effect, if the constitution be construed as it would have been construed, had the jurisdiction of the Court never been extended to suits brought against a state, by the citizens of another state, or by aliens.").

${ }_{12}$ Professor Marshall also suggests this possibility, but in a single sentence. See his letter above at 131 and see L. Marshall, 102 Harv L Rev at 1366-67 n 113 (cited in note 3). 
ferred citizen-citizen diversity jurisdiction on the federal circuit courts and forbade the manufacture of such diversity by assignment of choses in action by non-diverse to diverse citizens. Professor Massey construes $\S 11$ to forbid not just assignments to create party-based jurisdiction, but also assignments to create federal question jurisdiction when the assignment is made by a barred party, His only support is his invocation of Mossman $v$ Higginson ${ }^{13}$ and Hodgson $v$ Bowerbank. ${ }^{14} \mathrm{I}$ am at a loss to understand the relevance of these cases. Professor Massey does not state their holdings plainly, which may leave the reader unequipped to evaluate his arguments. The cases each held (not surprisingly) that diversity jurisdiction under $\S 11$ required more than an allegation that one of the parties was an alien; it also required an allegation that the other party was a citizen.

C. The Gallatin Amendment and Chief Justice Marshall's "Failure to Cement the Federalist Victory"

In arguing for his interpretation of the amendment,-Professor Massey relied on the rejection of an addition to the amendment proposed by Senator Gallatin. The addition would have excepted from the operation of the amendment "cases arising under treaties made under the authority of the United States."15 Professor Massey argued that the adopters rejected Gallatin's language because they intended to prohibit suits brought by out-of-staters and foreigners on any cause of action, whether treaty-based or not. My explanation of the rejection of Gallatin's amendment parallels that of Judge Gibbons: ${ }^{16}$ Gallatin's amendment would have preserved party-based jurisdiction in treaty cases, and Congress did not want that exception to the repeal of the state-citizen diversity clause. Hence, the adopters repealed the clause entirely. Professor Massey suggests that my explanation might assume that the anti-federalists were "willing to tolerate the possibility of claims against states under federal question jurisdiction." But, he says, I disabled myself from relying on that assumption by "conceding that the ambition of the Eleventh Amendment was to protect state treasuries."

Professor Massey's argument addresses the whole of the diversity explanation, not just the Gallatin amendment. I agree that the

is 4 US 11, 4 Dall 12 (1800).

149 US (5 Cranch) 303 (1809).

134 Annals of Congress 30 (Jan 14, 1794).

${ }^{16}$ John J. Gibbons, The Eleventh Amendment and State Sovereign Immunity: A Reinterpretation, 83 Colum L Rev 1889, 1932-38 (1983). 
adopters wanted to protect state treasuries. But this concern did not necessarily prevail over all others. It prevailed when state treasuries were at risk from suits, like Chisholm, based on nonfederal law brought under the state-citizen diversity clause, for there was little countervailing federal interest. But when violations of federal law were at issue, the relative strength of the claim of the state treasuries was diminished.

Professor Massey maintains, further, that I must explain why Chief Justice Marshall "failed to cement th[e] federalist victory when he was given the chance to do so" by holding that federal question jurisdiction permitted unconsented suits against the states. He has not fully come to grips with my explanation of the amendment. I contend that the amendment did not affect federal question jurisdiction, and that it did not resolve whether federal question jurisdiction was sufficient to subject the states to unconsented suits. Chief Justice Marshall did, indeed, leave open the difficult issue of federal question jurisdiction. But far from disproving my version of the diversity explanation, his waverings and evasions help confirm it. The federal question issue was both unresolved and very difficult-too difficult to be resolved by an amendment that overruling a case that relied only on a party-based jurisdictional clause and deciding only a question of non-federal law.

\section{Constitutional Amendment Instead of Legislation}

Professor Massey had argued that use of a constitutional amendment rather than legislation to overrule Chisholm supports the conclusion that the amendment was intended to prohibit suits brought by out-of-staters and aliens. If only a repeal of the jurisdiction was intended, he argued, Congress could have simply repealed $\S 13$ of the Judiciary Act, which paralleled the state-citizen diversity clause of Article III. I responded that a constitutional amendment was used for good reason. Attorney General Randolph had argued in Chisholm, and four of the five justices may have agreed, that $\S 13$ was unnecessary because the Court's original jurisdiction under the state-citizen diversity clause was self-executing. Thus, merely repealing $\S 13$ would have invited a reaffirmance of Chisholm. ${ }^{17}$

Professor Massey now argues that Congress's passage of $\S 13$ in the first place is inconsistent with this explanation. Congress may have thought that $\S 13$ was necessary to confer original juris-

${ }^{17}$ Fletcher, 56 U Chi L Rev at 1288-89 (cited in note 1). 
diction on the Court. ${ }^{18}$ But that is not the point. Whatever Congress thought in 1789 , the critical question is what the justices thought when they decided Chisholm.

Professor Massey argues, further, that I must account for the "virtual silence" of the four justices in order to maintain that they may have thought the Court's original jurisdiction self-executing. I think their silence most likely to indicate that they agreed with Attorney General Randolph. ${ }^{19}$ If four justices may have considered the Court's original jurisdiction to be self-executing, the only sure way to avoid a reaffirmance of Chisholm was to repeal the statecitizen diversity clause.

\section{Reply to Professor William Marshall}

I understand Professor William Marshall to agree that the Eleventh Amendment did no more than repeal the state-citizen diversity clause. However, for him, the "meaning" of the Eleventh Amendment also includes the set of questions involving state immunity to any private suit. Professor Marshall concludes that the Eleventh Amendment was adopted against a background of assumed state sovereign immunity to damage claims brought by private individuals under federal law. I am not as sure as Professor Marshall that the states were assumed to be immune from damage suits under federal law. Nor am I sure that an immunity to damage suits implied an immunity to unconsented suits under federal law seeking other relief. (Professor Marshall appears to believe that federal question suits seeking non-monetary relief may have been permitted.) I think that these were unsettled, and very difficult, questions that were left to be answered as the meaning of the Constitution unfolded.

18 I do not regard $\S 13$ as conclusive evidence that Congress thought the Supreme Court's original jurisdiction self-executing. 28 USC $\$ 1251$ (1982), for example, describes the Supreme Court's original jurisdiction, even though it is commonly assumed today that the jurisdiction is self-executing.

10 I previously indicated that Professor Clinton goes further, contending that at least Justice Wilson affirmatively agreed with Randolph. Fletcher, 56 U Chi L Rev at 1289 n 140 (cited in note 1); and Robert N. Clinton, A Mandatory View of Federal Court Jurisdiction: Early Implementation of and Departures from the Constitutional Plan, 86 Colum L Rev 1515, 1563-68 (1986). Professor Massey tries to undercut Professor Clinton's support for my conclusion, saying that Clinton "admits that Justices Cushing, Blair, and Jay did not 'directly address[] the debate." " Professor Clinton's full sentence is, "Justices Cushing, Blair, and Jay, while not directly addressing the debate between Justices Wilson and Iredell, nevertheless seemed closer to Wilson's mandatory view of Article III than to Iredell's suggestion that Congress had plenary authority over the scope of jurisdiction of the federal courts." Clinton, 86 Colum L Rev at 1567. 
A pamphlet written by Timothy Ford of South Carolina a year before the Court's decision in Chisholm supports the contention that it was at least an open question whether federal question jurisdiction supported unconsented suits against the states. ${ }^{20}$ James Sullivan, the Attorney General of Massachusetts, had written a pamphlet arguing that unconsenting states could not be sued in federal court by individuals. ${ }^{21}$ Ford's pamphlet was a direct response. $\mathrm{He}$ argued that the states were subject to unconsented suits not only under state-citizen diversity, but also under the federal question jurisdiction. After quoting the federal question jurisdictional clause of Article III, Ford wrote, "[The United States] may, therefore, pass laws, directly obligatory upon each state. If under one of those laws, so passed, a case should arise; that case, and necessarily the state, relative to which it should arise, would, from the very terms of this clause, be subject to the judicial power."22

Chisholm was decided and the Eleventh Amendment adopted with this argument in the air. Ford had contended that the states were suable under both state-citizen diversity and federal question jurisdiction. Yet the amendment addressed only out-of-state citizens, leaving the federal question issue unresolved. It is apparent that Ford was not stating a view as to which there was a general

${ }^{20}$ Timothy Ford, An Enquiry Into The Constitutional Authority Of The Supreme Federal Court, Over The Several States In Their Political Capacity (W.P. Young, 1792). The pamphlet is attributed to Ford. The authorship printed on the title page is only "By a Citizen of South Carolina."

I owe Professor William Marshall an apology for bringing Ford's pamphlet into the discussion so late in the proceedings. I am, as it were, supplementing the record on appeal. However, I only discovered Ford's and Sullivan's (see note 21) pamphlets in December, 1989, after I had reviewed galley proofs for Fletcher, $56 \mathrm{U}$ Chi L Rev at 1261. The pamphlets have never been discussed in the academic literature on the Eleventh Amendment. These pamphlets are available at the Harvard Law Library, Rare Books Collection.

${ }^{21}$ James Sullivan, Observations Upon the Government of the United States of America (Boston, 1791).

${ }^{22}$ Ford, Enquiry at 30 (emphasis in original). Ford also writes, "[T]he states, as well as the people, are made the subjects of federal legislation. Now, it is a truth, too evident, and too generally recognized to need demonstration, that in all governments, the judicial department must be co-extensive with the legislative. What the one commands, the other must decree the obedience of, and the executive must enforce it. All constitutional acts of power, proceeding from the executive and judicial, have as much legal validity, and import as much obligation, as those proceeding from the legislative department." Id at 18-19 (emphasis in original). "Without commenting upon every branch of this comprehensive sentence [of Article III], I shall select those which appear to have a reference to the argument under discussion. 1. 'It shall extend to all cases arising under this constitution, and the laws of the United States.' I must be under a great mistake if it has not already been evinced, that by this constitution every state in the union, as a state, is subject to the laws of the United States." Id at 29-30 (emphasis in original). 
consensus. Rather, he was arguing about an unresolved question. The existence of such an argument makes it difficult for Professor Marshall to contend that the Eleventh Amendment was adopted against a background consensus that the states were immune from damage suits.

Professor Marshall does make one point to which I do not have a wholly satisfactory answer. If there was a possibility that federal question suits seeking monetary relief could be brought against the states, he asks, why do we not find any discussion of this when Congress passed the general federal question jurisdiction statute in 1801, or when it repealed it in 1802? A possible answer is that the federal question suits that had troubled the adopters were by then no longer a pressing concern. Claims under the Treaty of Paris had been shunted off to an international commission. Claims concerning state public securities issued to finance the Revolution, already largely assumed by the federal government even at the time of the Eleventh Amendment, do not appear to have been an issue by 1801 and 1802. And claims against the states for repudiation of land contracts were not squarely cognizable under the Contract Clause until Fletcher $v \mathrm{Peck}^{23}$ in 1810. Another possible answer is that federal question suits may have been possible in the state courts. But I am skeptical of this answer because of the uncertainty surrounding the ability to bring suit in the state courts, as well as the superiority of the federal forum for plaintiffs. All in all, I regard the absence of discussion in 1801 and 1802 as a point for Professor Marshall.

I find Professor Marshall's other arguments less troubling. $\mathrm{He}$ points to statements by prominent federalists that states should not be subject to federal suit for monetary relief, but these comments addressed claims under state-citizen diversity jurisdiction, not under federal question jurisdiction. He also argues that characterizing Chisholm as a misuse of a state's own law misconceives the threat it posed to state treasuries. I agree. The Court in Chisholm did not base its holding on state law. Rather, it held that the state's sovereign immunity had been overridden by superior federal law, operating (to use an imprecise modern analogy) as a sort of in personam jurisdictional statute requiring the state to appear before the federal court and defend the contract suit on its merits. But the underlying obligation was based on non-federal law, the common law of contract. Because the violation of a federal duty 
was not at stake, the adopters of the Eleventh Amendment could reasonably have concluded that the interests of the federal government were not sufficiently involved to justify imposing monetary liability on the state.

In the end, I regard Professor Marshall's position as a variant of the diversity explanation. I understand him to agree that the amendment did no more than repeal the state-citizen diversity clause. We part company on what remained after the repeal. $\mathrm{He}$ thinks that non-monetary relief may have been available against the states under federal law, but that monetary relief was assumed to be unavailable. I think that the availability of both monetary and non-monetary relief was an open question. But this disagreement goes to the nature of the federal question jurisdiction, not to the meaning of the Eleventh Amendment. I think that Professor Marshall is a "diversity theorist" malgré lui. 